\title{
Framing and fundraising: Emotional language and money raised in a Vietnamese newspaper column
}

\author{
Hong Van Pham Thi \\ West Virginia University
}

Follow this and additional works at: https://researchrepository.wvu.edu/etd

\section{Recommended Citation}

Pham Thi, Hong Van, "Framing and fundraising: Emotional language and money raised in a Vietnamese newspaper column" (2010). Graduate Theses, Dissertations, and Problem Reports. 4642.

https://researchrepository.wvu.edu/etd/4642

This Thesis is protected by copyright and/or related rights. It has been brought to you by the The Research Repository @ WVU with permission from the rights-holder(s). You are free to use this Thesis in any way that is permitted by the copyright and related rights legislation that applies to your use. For other uses you must obtain permission from the rights-holder(s) directly, unless additional rights are indicated by a Creative Commons license in the record and/ or on the work itself. This Thesis has been accepted for inclusion in WVU Graduate Theses, Dissertations, and Problem Reports collection by an authorized administrator of The Research Repository @ WVU. For more information, please contact researchrepository@mail.wvu.edu. 


\title{
FRAMING AND FUNDRAISING: EMOTIONAL LANGUAGE AND MONEY RAISED IN A VIETNAMESE NEWSPAPER COLUMN
}

\author{
Hong Van Pham Thi
}

Thesis submitted to the Perley Isaac Reed School of Journalism at West Virginia University in partial fulfillment of the requirements for the degree of

\author{
Master of Science \\ in \\ Journalism
}

\author{
Approved by \\ Diana K. Martinelli, Ph.D., Committee Chairperson \\ George Esper, Ph.D. \\ Bob Britten, Ph.D. \\ Neal Newfield, Ph.D.
}

The Perley Isaac Reed School of Journalism

\author{
Morgantown, West Virginia \\ 2010
}

Keywords: emotional phrases; framing; money raised; Vuot Len So Phan; Vietnam 


\section{Abstract \\ Framing and Fundraising: Emotional Language and Money Raised in a Vietnamese Newspaper Column Hong Van Pham Thi}

This exploratory study examined Vuot Len So Phan, a Vietnamese philanthropy newspaper column in Sai Gon Tiep Thi, a Vietnamese newspaper from April to December 2009. Guided by framing literatures, 39 episodic frames stories portraying financially disadvantaged people were content analyzed in terms of demographics of the featured subjects and emotional phrases used in the stories. The hypothesis predicting a positive correlation between emotional phrases and money raised was supported. This means the more emotional phrases used in an episodically framed story, the more money it was likely to raise. This study found an unexpected result that donations were declining over time and stories that ran earlier in the series had a tendency to receive more donations than stories that ran later on. Photographs and demographics variables of featured subjects did not have a significant relationship with money raised with the exception of the variable of ethnicity. A moderate, positive correlation between the number of donors and the amount of donations received was found. 


\section{Acknowledgements}

I would like to thank Dean Maryanne Reed and the faculty and staff at the Perley Isaac Reed School of Journalism for their support and guidance throughout my graduate years at West Virginia University. I was given the news skills, knowledge and confidence to join the professional world as a journalist and a researcher.

This thesis could not have been finished without all of the help, support, and encouragement of members of my committee. A special thank you goes to Widmeyer Professor in Public Relations, Diana K. Martinelli, as well as Professor George Esper, Professor Bob Britten and Professor Neal Newfield. Each member of my committee served as a wonderful mentor and provided me with excellent resources and guidance that allowed my study to be possible.

I would also like to thank Emeritus Professor at An Giang University, Professor Vo-Tong Xuan, who introduced me to West Virginia University and agreed to help with the coding process of this study. I would like to thank my friend and a Graduate assistant at the College of Human Resources and Education, Phillip Adu for his help with the statistical tests.

Thank you to Dr. Steve Urbanski who always said to me: "I am here to help”. He also spent hours and hours helping me with my papers, gave me a ride home and encouragement when I was sad. Thank you to Brenda Sisler for showing me how to run the copy machine and smiling with me. Thank you to Becky Jones-Pierce who gave me her keys to get into 104, talked with me when we had lunch together and made me smile. 
Thank you to Professors Ivan Pinnell and Sammy Lee for their love, caring and support. Thank you to Professor Joel Beeson who reminded me of my father with his eyes. Thank you to Professor Lois Raimondo who welcomed me into her advanced photojournalism class and gave me great advice when I was sad.

There are many people whom I love here in Morgantown, my home away from home. I would like to thank each of my classmates and my Vietnamese friends: Nicole Lemal, Nicole Fernandes, Michael Conti, Jee Eun Seymour, Boya Xu, Heather Sager, Alissa Murphy, Chi Ngo, Hieu Le, Quang Phuong, Anh Truong, Tuan Le, Tam Schlosky, Trang Nguyen, and Kevin Nguyen. And a special thank to Paula Herbst, my host mother, who provided me with a safe and warm place to live.

I also wish to thank my parents, my sisters and Hieu Nhan, my childhood friend. They always think about me and have been there to support my educational endeavors. I appreciate all they have given me and for making it possible to pursue my educational goals. 


\section{TABLE OF CONTENTS}

ABSTRACT ii

ACKNOWLEDGEMENTS ........................................................................................ iii

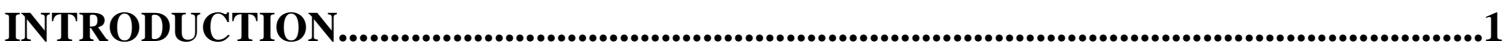

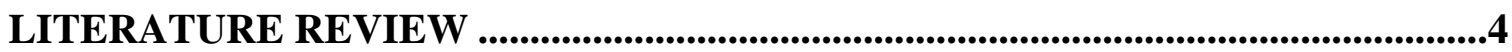

The Socialist Republic of Vietnam .........................................................................4

The media in Vietnam.....................................................................................6

Readership and philanthropy activities of Vietnamese newspapers .........................8

Framing ................................................................................................................................10

Episodic framing .................................................................................................................11

Emotional effects ..........................................................................................12

The poor in the media ......................................................................................................14

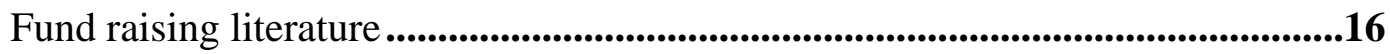

Photographs as visual effects in the media ......................................................18

Research questions and hypotheses ....................................................................18

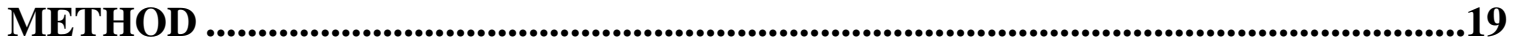

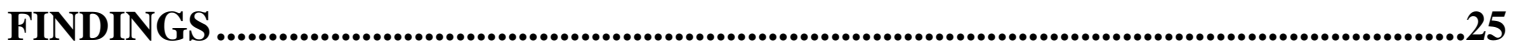

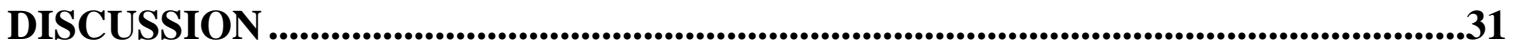

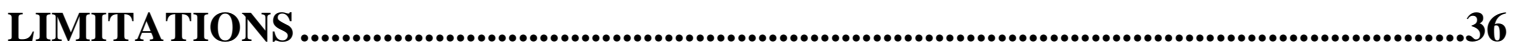

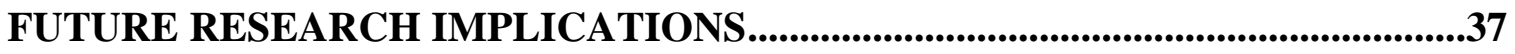

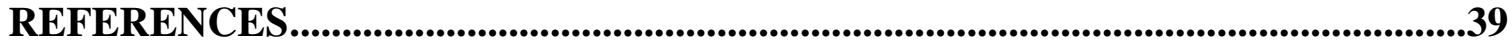

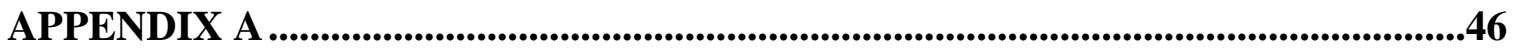

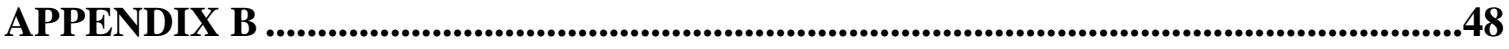

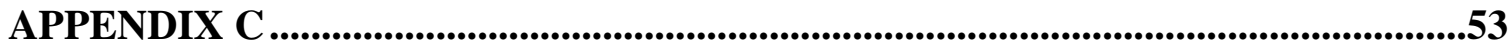




\section{Introduction}

According to Hoang Tuyen, Chief Deputy of Can Tho Bureau of Sai Gon Tiep Thi newspaper, based in Can Tho, Vietnam, Sai Gon Tiep Thi weekly magazine was started June 14, 1996. It first belonged to Ho Chi Minh City People Committee. Sai Gon Tiep Thi focuses on trade, marketing and financial issues and targets the market segment

of businessmen and entrepreneurs. On January 15, 2004, the ownership was transferred to the Trade and Investment Promotion Center of Ho Chi Minh City. In 2005, the magazine received the license to open its digital website, and on July 1, 2007, the magazine was allowed to run three days a week.

Its target customers mostly live in big cities such as Ho Chi Minh City, Ha Noi, Da Nang, and Can Tho. Because Sai Gon Tiep Thi finds it hard to compete with other daily newspapers with breaking news, the newspaper differentiates itself among 700 Vietnamese newspapers and magazines by reporting with commentary and the emotional expression of the journalists, allowing more personal remarks and thoughts. Most other print media prefer reporting events in a more objective style.

Before the economic downturn hit Vietnam in late 2008 and 2009, Sai Gon Tiep Thi's circulation was above 100,000 issues a day. During the financial collapse, its circulation decreased to below 100,000 issues a day, but it still remains high roughly equivalent to the other newspapers it competes with. One single newspaper is purchased at the price of 2,700 Vietnam dong, which is equal to 6.7 cents in US dollars (HoangTuyen, personal communication, November 15, 2009).

In March 2009, Sai Gon Tiep Thi ran Vuot len so phan (Overcome the Destiny), a brand new column, featuring financially disadvantaged people for its Friday publication. 
Each story can be found in its print, digital version at (http://www.sgtt.com.vn). A 15minute video for each featured subject was also produced by Sai Gon Tiep Thi and is broadcasted weekly on VTV9, a nationwide television channel, on Monday night and Thursday morning. Each featured subject in the story will be given 10 million Vietnam dong, which is equal to $\$ 550$ U.S., to enhance his or her life, plus he or she receives the money donated by viewers after the stories have been run.

Vuot Len So Phan's subjects are poor citizens or students who faced financial problems and adversity. They had the commitment to overcome their obstacles, but their efforts have not yet received rewards. The paper's philosophy is not to emphasize the deadlocked situation, but the goodwill, commitment and beauty inside of the poor featured people (Mặc-Lâm, 2009; Vo, 2009). Journalists involved in bringing the stories to the public said that the stories themselves and the money given was only a small support for the characters to continue fighting against poverty and that it offered little help and justice for them. Vo Dac Danh, founder of the series, said that the featured subjects' goodwill, commitment and kindness mirrored the beauty of true human beings. If people from well-off classes were in the same situation, they might not behave like them. The donations were considered the fee the readers and viewers pay for learning some lessons from the characters (Vo, 2009).

Asia Commercial Bank (ACB) is Vuot Len So Phan's executive sponsor. The bank provides 140 million Vietnam dong, which is about one fourth of the total money needed (520 million) to support the column for a year. As the column aims to feature 52 financially disadvantaged subjects in the time frame of 52 weeks, the rest of the money comes from fund-raising by the newspaper itself (Vo, personal conversation, November 
15, 2009). Money donated by the readers that was not specified to go to a particular person goes to the general budget. The money that was addressed to a specific character would be directly sent to the person. Along with money, other types of support are also made available, such as job offers, safe house offers, health care treatments and scholarships. These gifts also can significantly change lives. In every story run on Sai Gon Tiep Thi newspaper and its website, there was repeated information of the hotline and Sai Gon Tiep Thi newspaper's email if one wanted more information or to make a donation. When the video is broadcast on VTV9, the running line with the address of Sai Gon Tiep Thi newspaper, where all the donations are suggested to be sent, appeared on the screen. Money raised and other donations are updated on a weekly basis. This information is announced by the anchor and easy to access on the newspaper's website. However, the campaign did not distinguish whether the money raised comes from newspaper readers or television viewers. According to Vo Dac Danh, the information provided about each character is consistent in the newspaper/ website and the video; however, the medium differs.

In spite of this limitation, this study attempted to explore how the print stories are framed and if there is a correlation to the amount of money donated to the profiled individuals. Specifically, this study examined framing and fundraising literature to explore the use of emotional phrases in media and the resultant money donated by readers. Ultimately its findings might be used by organizations to help with future fund raising activities or extrapolated to explore the other media used. 


\section{Literature review}

\section{The Socialist Republic of Vietnam}

The website of the U.S. Central Intelligence Agency, world fact book session about Vietnam, provides a clear and concise history of Vietnam from 1958 to the present. Vietnam had a thousand years of feudal history before Western culture came to the nation with the French colonists in 1958. The French officially finished establishing rule in Vietnam in 1884, but still faced numerous rebellions. Together with Vietnam, Laos and Cambodia made up French Indochina in South East Asia.

Vietnam was occupied by and battled with France, China, and Japan (Tenenbaum, 1996) before the nation declared independence on September 2, 1945. However, Vietnam fought against the French until its 1954 defeat by Communist forces lead by Ho Chi Minh, who was later called the father of the nation.

Under the Geneva Accords of 1954, Vietnam was divided into North and South with two different political orientations. Communist North Vietnam, headed by Ho Chi Minh, had a tight relationship and connection with other communist nations such as China, the Soviet Union and Cuba. The South of Vietnam was Republican and anticommunist oriented. American economic and military aid to South Vietnam grew through the 1960s in an attempt to bolster the South Vietnamese government. However, the United States armed forces were withdrawn following a cease-fire agreement in 1973. Two years after the last American troops left Vietnam, the Communist force took over the country and put the two parts of Vietnam under Communist rule.

Planning and a non-market economy orientation was widely and strictly applied for over a decade of peace after April 30, 1975. Vietnam experienced little economic 
growth because of conservative leadership policies, the persecution and mass exodus of individuals, many of them successful South Vietnamese merchants, and growing international isolation. However, with the enactment of Vietnam's "Doi moi" (Renovation) policy in 1986, Vietnamese authorities committed to increased economic liberalization and enacted structural reforms needed to modernize the economy. This reform policy was focused first on the agricultural sector, which experienced a marked increase in rice and other agricultural production (General Statistical Office, 2001), and the development of more competitive, export-driven industries. Prior to the Doi moi reforms, Vietnam was importing rice despite widespread adoption of modern rice varieties and government technology (Pingali \& Vo-Tong, 1992). In 1989, Vietnam for the first time exported 1.4 million tons of rice and continued to increase the amount of rice exported in the following years ("Việt Nam," 2006, para. 3). Now Vietnam is the world's second largest rice exporter ("World rice exports," n.d, para. 1, "Thailand," 2006).

Vietnam has the $14^{\text {th }}$ largest population in the world with an estimated $86,967,524$ people, based on July 2009 statistics (Central Intelligence Agency (CIA), 2010). The country significantly shifted from having a 58 percent poverty rate in 1993 to $16 \%$ in 2006 (World Bank, 2008, para. 20). However, the official statistical estimate about Vietnam poverty rate by the Labor, Invalids and Social Affairs (MOLISA) is only 15 percent while Minot and Baulch (2005) finds it is 41 percent. As Minot and Baulch (2005) use a different method to approach poverty issues in Vietnam, they found that the gap between the Vietnamese official poverty statistic and their statistic is up to 76 percent different (6 percent versus 82 percent). 
Poverty in Vietnam is concentrated among ethnic minorities who live in remote mountainous areas, with up to 90 percent of the population living below the poverty line (Minot \& Baulch, 2005). However, there are also significant pockets of poverty among the rural majority Kinh people. Even with increased rates of urbanization, the majority of people live in rural areas ( 80 percent of the population) and remain engaged in agriculture (60 percent of the workforce). Gender also remains a significant determinant of poverty in Vietnam. Ethnic minority girls continue to lag behind both Kinh girls (10 percent gap) and ethnic minority boys (13 percent gap) in terms of school enrollment ("Vietnam," n.d.).

Vietnam does not own the symbol of "melting pot" or "salad bowl" like America does. The nation's population is fairly homogeneous with more than 86 percent of people being Viet who mainly inhabit the lowland delta region, and the remaining 14 percent being distributed across the other 53 different ethnic minorities (Fliert \& Do, 2009). There is a general feeling that racism is not a big problem in Vietnam. As the minorities, which include Tay 1.9\%, Thai 1.7\%, Muong 1.5\%, Khome 1.4\%, Hoa 1.1\%, Nung 1.1\%, Hmong 1\%, and others $4.1 \%$ according to a 1999 census (CIA, 2010), are small in number and power, national self-supported newspapers or high circulation newspapears rarely cover stories about these small groups.

\section{The media in Vietnam}

Vietnamese journalism started its history September 29, 1861, with Le Bullentin Officiel de L'Expedition de la Conchinchine. This is a governmental gazette in French for Vietnam, a colonial country of France. The first Vietnamese language newspaper, Gia Định, came four years later on April 15, 1865 (Lam-Dien, 2005; Vietnamjournalism, 
2004, para. 3). This year marked the starting point of Vietnamese journalism, as many historians and scholars widely agreed.

The day of June 21 is celebrated yearly as the Vietnamese Renovation Journalism Day in Vietnam to mark Thanh Niên weekly, founded by Nguyễn Ái Quốc, another alias of Hồ Chí Minh, which first came out on June 21, 1925 (Thanh-Hoang, 2007, para. 8). According to many different sources, Vietnam has more than 700 news agencies, about 15,000 licensed journalists, more than 50 official online news websites and thousands of unofficial websites (Việt-Văn, 2008; Hà-Anh, 2009). Local government newspapers still receive a government budget while the remaining news offices are selfsupported. Each newspaper is an organ of a department or of a State organization. The Deputy Minister of Information and Communications of the Socialist Republic of Vietnam, Do Quy Doan, remarks that there is no private media in Vietnam ("Khong cho", 2008). Even the blogs must be put under the control and supervision of the authorities. "A blog is a personal news page. If a blogger uses it for general news like the press, he is breaking the law and will be punished," Do Quy Doan said in February 2009 (Internet enemy, 2009, p. 27).

Vietnamese media have been criticized by organizations such as Committee to Protect Journalists and Reporters without Borders for being an Internet enemy and for tightly controlling press freedom. However, Vietnam authorities deny these accusations by saying that Vietnam has its own law and journalists or citizen bloggers should respect the law of Vietnam. 


\section{Readership and philanthropy activities of Vietnamese newspapers}

In general practice, Vietnamese newspapers often run "thank you" messages to their readers for the money they donate for the recently portrayed subjects. These messages are placed in "The readers and us," a special column that carries information about the relationship and connection of the readers and the newspapers. For the first month after starting the Vuot Len So Phan column, Sai Gon Tiep Thi ran "thank you notes" under stories; then it created a separate digital page just for this donation information. At the administration level, some newspapers even have a Social Work Division (H-Dieu, 2010, para. 1; Phuc_Dien, 2010, para. 17). Employees for the newspapers' social work divisions are not required to write stories but to organize and arrange charitable and social events run by the newspapers.

“Thông tư 72/2008” (Act 72/2008), enacted in 2008 in Vietnam, banned all organizations, including the press, from doing fund raising and being directly involved in distributing money and goods for relief or charity. "Mặt trận tổ quốc," is the one task force allowed to coordinate all fund raising for philanthropy purposes. This Act caused an extreme debate in Vietnam. Most did not support it. In the article ““‘Độc quyền” làm từ thiện, lợi hay hại?" (Exclusive in Charity works, should or should not?) (Tra-Giang, 2008), the author pointed out that (1) newspapers raise funds quicker and more effectively than the exclusive task force, (2) people prefer to give money to the newspapers because they can be invited to the relief activities, directly give the money to the people in need without worrying that their money will be used for other purposes and (3) since the Act was applied, the money raised was very little (3 percent) compared with 2007, the year before. This can be seen as an example of the effectiveness of charity 
works run by the newspapers in Vietnam and how the people respect these events. To solve this problem, then there was an agreement to let media organizations raise funds. However, they have to report the amount of donations to Mat Tran To Quoc. Mat Tran To Quoc will then issue a letter of declaration giving newspaper A or magazine B the power of attorney to do charity.

Every year, for general occasions, such as before the Lunar new-year festival or after severe typhoons or hurricanes, it is a tradition for Vietnamese media to engage in fund raising activities. The Vietnamese National Television network operates telethons to raise funds for the poor while concurrently, newspapers call for donations from their readers. Newspaper agencies in Vietnam are destinations for goods and money donated (because they have the Social Work Division). They directly distribute money, food, clothes and/or medicine to different areas to people in need (Tra-Giang, 2008).

In the case of Sai Gon Tiep Thi, the newspaper received and delivered donations for single cases featured in single articles. However, it is the first time this newspaper ran a long-term fund raising campaign toward financially disadvantaged people with the promise of some basic support. The characters featured in these stories received money; however these donations tended to be disproportionate. There is a general belief among the Vietnamese that the level of poverty is far beyond the official number and the poverty rate of Vietnam remains high (Vo, 2009). It is the Sai Gon Tiep Thi's responsibility to choose the deserving subject. The prediction that all the subjects in the stories are deserving poor suggests that Vietnamese journalists will employ episodic frames and emotional language to persuade the readers to donate money afterward. 


\section{Framing}

Framing research is common in many different fields of social science, ranging from descriptive and analysis purposes, psychology, linguistics and discourse analysis, communication and media studies to political science and policy studies (Benford \& Snow, 2000). It is the technique through which social problems are constructed. Framing theory posits that the way in which information is presented, or the perspective taken in a message, influences the responses individuals will have to the issue at hand (Nabi, 2003). Entman (1993) finds that issues can be framed by a set of competing values by potential beneficiaries to make them more salient in a communicating text to promote a particular problem definition, causal interpretation, moral evaluation, and/or treatment recommendation.

The credibility of a frame is comprised of three salient elements: frame consistency, empirical credibility, and credibility of the frame claimsmakers (Snow \& Benford, 1988). Frame resonance has to do with a collective action frame which is affected by its salience to targets of mobilization through (1) centrality, (2) experiential commensurability, and (3) narrative fidelity (Benford \& Snow, 2000). Centrality’s function is to connect the essential beliefs, values, and ideas associated with the movement frame and the targets of mobilization. Experiential commensurability has to

answer questions such as are "framings congruent or resonant with the personal," "are the frames too abstract and distant from the lives and experiences of the target" (Benford \& Snow, 2000, p. 621). Narrative fidelity is considered the overall impact a frame has on the world. A good narrative fidelity ultimately contributes to overall mobilization. After 
all, there are specific desired outcomes that relate to how organizational, political, tactical, and framing variables interact and are combined (Benford \& Snow, 2000).

\section{Episodic framing}

Iyengar (1991) distinguished thematic and episodic frames into two opposite positions. Episodic frames present social problems as an individual exemplar while thematic frames tend to describe the topic as collective cases to emphasize the issue as large social problems. Gross (2008) finds that episodic frames were more emotionally engaging. Stories with episodic and thematic frames "lead readers to focus on different aspects of a social problem and to assign responsibility consonant with how the problem is defined" (Gross, 2008).

News coverage adopts episodic frames to emphasize events or individuals. "Episodic frames present an issue by offering a specific example, case study, or event oriented report (e.g., covering unemployment by presenting a story on the plight of a particular unemployed person)" (Gross, 2008, p.171). More specific, Myhre, Saphir, Flora, Howard and Gonzalez (2002) say episodic frames lead readers to focus on solutions involving individual responsibility. Gross (2008) finds that episodic framing alters emotional response relative to a thematic article on the same topic. If the main character of the story cannot arouse persuasive emotions in the readers, the persuasive appeal is more likely to fail. Readers of episodic framing stories were significantly more likely to express sympathy and pity. Compared to thematic frames, episodic frames seemed to have greater impact on the readers and produce and maintain its persuasive effects over a longer period. 
Gross' (2008) findings seem to both reinforce and extend Iyengar's (1991).

Episodic frames emphasize individuals and therefore produce individual attributions. In addition, episodic frames can actually increase persuasion if the individual's story is compelling enough to generate intense emotional reactions from a significant portion of the audience. Iyengar and Kinder (1987) also noticed the differences in the effects of episodic frames based on the race (white and black) of the featured subjects.

A study of Mastin, Choi, Borboza and Post (2007) on news coverage of elderly abuse suggests that newspapers consistently portray the issue as an individual problem with individual solutions and more episodic frames were applied in news report than thematic frames.

\section{Emotional effects}

Gross (2008) finds that emotional appeals are an important element of any persuasive message and episodic framing is more emotionally engaging. Such appeals represented in the media, news stories, advertisements, or entertainment programs often aim to capture attention, influence attitudes, and affect behavior. To be consistent within frames, emotions should affect the way in which information is gathered, stored, recalled and used to make particular attributions or judgments (Nabi, 2003). An example is a study about moral heuristics, a topic that attracts much commentary by Sunstein (2005), who explains how different language uses arouse different emotional reactions in readers. Sunstein (2005) compares two situations:

a) "Company A knows that its product will kill ten people. It markets the product to its ten million customers with that knowledge. The cost of eliminating the risk would have been $\$ 100$ million. 
b) Company B knows that its product creates a one in one million risk of death. Its product is used by ten million people. The cost of eliminating the risk would have been $\$ 100$ million” (p. 536).

According to Sunstein (2005), company A will be punished more severely than company B even though there is no difference between them but the way of expression. Company A's statement directly leads the readers into thinking about the number of people lost while Company B's statement is more likely a probability of a worse situation than might happen. Sunstein's study (2005) attracted many commentaries from scholars, such as: (1) moral and emotional understanding of the situation is influenced by reader's age (meaning life experience) and by their emotional intelligence, especially by their level of understanding emotions; (2) quality of moral decisions is very sensitive to emotions, and that emotional intelligence might determine decisions in different moral tasks; (3) moral heuristics are not rigid but are flexible and demonstrate the general belief that emotional cognitions can lead to adequate moral behaviors.

Goldie (1999) argues that people understand one another by a four-step process of decoding emotions: (1) emotional contagion, (2) empathy, (3) in-his-shoe imaging and (4) sympathy. According to Goldie (1999), it is impossible for a person to sympathize without empathizing what others feel. In other words, emotional feelings influence people's responses.

Many studies find direct and indirect relationships between frames and emotional responses of people (Damasio, 1994; Gross, 2008; Gross, \& D’Ambrosio, 2004). These studies suggest that by highlighting certain aspects of an event or policy, by adhering to certain issues, themes and/or tone, frames will guide an audience's thoughts about that 
particular issue or event in predictable ways, and therefore, even the conclusions can be predicted (Brewer, 2001). Framing extends to emotion (Kinder \& Sanders, 1990) and emotional responses (Brewer, 2001; Nabi, 1998). Different people react differently to a given frame. Individual assessments depend not only on the information available in the frame but also on how that information fits with one's value. Researchers find that the negative attitudes of anger, disgust, and fury were associated sharply with opinions of affirmative action as an "unfair advance frame" while affirmative action as severe discrimination did not (Gross and D’Ambrosio, 2004).

Brewer (2001) and Nabi (1998) find that the persuasive effect of a frame depends on the degree of emotional reactions people may have. These studies are supported by Gross and D'Ambrosio (2004), who find that frames do alter the relationship between predispositions and emotions in the case of pity, and frames may be central to people's ability to make good choices. In other words, emotional responses may be the consequence of the frames' persuasion effect on targeted consumers.

\section{The poor in the media}

Gans (1995) finds that Americans automatically believe people of the underclass are undeserving and label them as lazy, as unable to learn cultural knowledge and skills, and as street criminals. A study by Hodgetts and his colleagues (Hodgetts, Hodgetts, \& Alan, 2006; Hodgetts, Masters, \& Robertson, 2004) finds that news constructions are important because coverage of such social issues as poverty is often used by policy makers. Barnett, Hodgetts, Nikora, Chamberlain, and Karapu (2007) later suggested that news agencies are primary sources for understanding social concerns. The media are central to the definition of social issues and the legitimization of specific approaches to 
these issues (Hodgettes, Cullen, \& Radley, 2005). Therefore, understanding how the media portray the financially disadvantaged is important to understand public opinion about poverty issues.

From the United States to New Zealand, Britain and Vietnam, numerous studies provide a fairly wide explanation about portrayals of the poor in the media (Golding \& Middleton, 1982; Gilens, 1996; Gans, 1995; Clawson \& Trice, 2000). Regardless of the researchers' various geographic distributions, they all reached similar conclusions that the media portrayed an inaccurate picture of the demographic characteristics of poor people (Gilens, 1996); they overrepresented and emphasized more poor black people than white people through overused photos and the frequency of coverage of black poor (Gans, 1995). More specifically, studies blame media for showing stereotypes and closely relating poor Americans with race, crime and discrimination (Clawson \& Trice, 2000; Gilliam, Valentino, \& Beckmann, 2002; Iyengar, 1991). Negative, exaggerated coverage influences the attitudes and responses of those exposed to these stories (Gilens, 1996, Iyengar, 1991). Gans (1995) argues that overrepresented news stories about "undeserving poor" people hurt the images of the legitimate poor. Therefore, both deserving poor and taxpayers think the "bad" poor are their burden. Undeserving poor were blamed for relying on welfare money and for being street criminals.

A study by Couldry and Curran (2002) quoted in Barnett et al. (2007) suggests that people in poverty are not constructing their own image; "rather, they are constructed by others in a manner that often appeals to public prejudices, and legitimates punitive government policy responses" (p. 297). Gans (1995) and Devereux (1998), as quoted in a study by Barnett et al. (2007), find that the media regularly frame stories about the poor 
by contrasting the "good" poor and "devil" poor or the deserving and undeserving. Children and elderly people are often framed as innocent and portrayed as needy victims or deserving poor, while unemployed people were accused of being shy of work and overly dependent on taxpayers. Black women were negatively portrayed as adolescent mothers with immoral sexual behavior (Gans, 1995; Golding \& Middleton, 1982; Clawson \& Trice, 2000). Barnett and his colleagues (2007) suggest that: "The academic research focusing on the power of media to silence can lead to cynicism and inaction because the news production is a closed system only engaged in by powerful political and social elites" (p. 298).

Studies about issues related to poverty in Vietnam find the relationship of poverty and age and gender inequality (Giang \& Pfau, 2009; Evans \& Harkness, 2008), while other researchers approach the aspect of the head of the family's education level (Thang \& Popkin, 2004) and their geographic scattering (Minot \& Baulch, 2005). However, these studies about poverty as a Vietnam social problem do not mention people's perceptions, prejudices or media stereotypes about the poor in Vietnam.

Gans (1995) suggests that although there are many negative labels about the poor, the positive labels also exist, "such as those used by some Marxists and Christians to romanticize the poor" (p.12). As Vietnam is a communist country heavily influenced by Marxism, it can be surmised that there is more positive coverage about poor people than negative coverage in the media and the images of poor are often drawn as deserving poor.

\section{Fund raising literature}

Kelly (1991) demonstrates the lack of research in the field of fund raising, and efforts to find relevant literature for this study continue to confirm it. A definition of fund 
raising has not yet been standardized because researchers approach fund raising from many viewpoints. In general, fund raising is widely understood as an activity run by fund raising specialists of organizations that solicit and accept gift from individuals, corporations and foundations. Carbone (1986), cited in Kelly (1991), says that fund raising is everything associated with solicitation, from institutional advancement to philanthropy. Fund raising is often used interchangeably with philanthropy and charity (Kelly, 1991). Together with public relations, fund raising involves not only seeking and accepting gifts but also developing understanding and support from its public. According to Kelly, education is one important field of fund raising. Fund raising's core role sits in coordinating donors to overcome the equilibrium at zero contribution (Andreoni, 1998) to make an action of giving.

One of many ways to measure fund raising performance is by effectiveness and efficiency (Grunig, 1995). "Effectiveness is the extent to which an object has the expected effect or serves the intended purpose" and efficiency is defined as the "ratio of the useful output to the total input in any system or the relative amount of effort needed to achieve a specific purpose" (Grunig, 1995, p. 688). A study by Jones and Hopkins (1985) supports Grunig's (1995) finding and suggests that the range of contributors to a fund raising campaign should be measured by (1) the number of contributors and (2) the amount of contributors. The author did not mention about the frequency of contributors. Supporting this finding, Howe (1985), cited in Kelly (1991), summarized fund raising as selecting "the right person to ask the right person, in the right way, for the right amount, for the right reason, at the right time" (p. 83). 


\section{Photograph as visual effect in the media}

Visual messages shape how people learn about other individuals, events, and issues (Franklin \& Iyengar, 2000). Images add a dimension of information not available solely through the printed word. Bissell (2000) suggests that the visual news presented in the newspaper offers readers a "slide of life" (p.12) and the decision that the news photographic editor made when selecting the news photo are subjective and based on individual bias. Regarding Bissell's findings, however, Seelig (2000) adds that photo editors are mostly responsible for the decisions in assigning reporters and photojournalists to stories. They have an underlying professional philosophy to publish news photos that are visually newsworthy, appealing, powerful, and informative.

Photographs have been charged with “altering people's minds and rearranging their lives” (Goldberg, 1991, p. 7), and Barry (1997) says images can affect moral judgments of people. Consistently, in a study about how photographs of political candidates can affect people's attitudes, Barrett and Barrington (2005) claim that people's attitudes are influenced by visual messages, that visuals specifically affect how candidates are perceived and this can be a motivator to vote for a certain candidate. A study by Coleman (2006) finds that photographs have the ability to improve participants' ethical reasoning and are consistent in identifying one variable as significant in that process: thinking about stakeholders and the people affected by an ethical situation.

\section{Research questions and hypothesis}

Drawing from the previous literature, this study looked at the Sai Gon Tiep Thi feature stories in the context of emotional language and episodic frames or themes used and the corresponding amount of money raised. Severity frames are defined in this study 
as episodic frames that denote sadness, pity, and insecurity caused by health problems, financial burden, overwhelming responsibilities and other unexpected hardships happening to the featured subjects. There were two exploratory research questions to test the two hypotheses:

$\boldsymbol{R Q}$ 1: What are the demographics of the financially disadvantaged people portrayed in the Sai Gon Tiep Thi newspaper of Vietnam?

$\boldsymbol{R Q} 2$ : Is there a correlation between specific demographics and money raised?

RQ3: What, if any, patterns are there in terms of photographs used and the amount of money raised?

H1: The more emotional phrases used in the article, the more money is donated to the featured subject.

H2: The more episodic frames, or severity themes, used, the more money is raised for the featured subject.

\section{Method}

Content analysis was used to examine Sai Gon Tiep Thi news stories in the Vuot len so phan column (Berger, 2000; Thayer, Evans, McBride, Queen, \& Spyridakis, 2007). Regarding the fact that content analysis cannot by itself reveal content effects, but can only provide a description of the communication, this study took this analysis one step further and also looked at money raised as one possible indicator of content effects.

Vuot len so phan's first story was published on April 6, 2009, in the form of an episodic frame story that portrayed one financially disadvantaged character. This column is run weekly on Friday. By the end of December 2009, Sai Gon Tiep Thi had run 39 such stories. The census of these consecutive 39 stories was content analyzed. In this period of time, there was not a specific occasion when people would traditionally want to make more donations than usual. For example, Vietnam celebrates Christmas but this is not a 
national holiday and this is not a giving season. As there was not any specific season that Vietnamese people tend to give more, this study acknowledges the fact that the readers' context is always wider than the story context and content analysis is only a method to describe the stories.

Effects of visuals are obvious and the media try to use them in creative and productive ways in their practice. Vuot len so phan's team combined video and photos with textual stories to approach the larger audience and make the story more salient. Although the priority of this study is to analyze the emotional language in the article and how it correlates with the money raised over one month, this study's researcher recognized that visual devices such as photographs could elicit strong emotional effects. Therefore, this study also conducted a simple coding to account for the photographs that ran along with the article. Photographs were categorized by the number of photographs, location of person (at home, at work, or others), persons in photo (featured subject only, featured subject with his/her significant ones and the significant ones of the featured subjects only) and tones of the photographs (negative, neutral or positive).

In studies examining the effects of emotional language, no clear and concise operational definitions were found. However, the researchers provided several examples, such as words like "hunger" or "thirsty," which were judged to be "physiological" because they are straightforward physiological arousal conditions with clear resolutions (Wolman, Lewis, \& King, 1971), while abstract words like "nervous" or “anger" or "anxious" or "happy" were judged to be less "physiological" and more "psychological" and were used as emotional words (Besemeres, 2004; Wolman, Lewis, \& King, 1971). A study by Oxburgh, Williamson and Ost (2006) supports the above agreement by saying 
that sadness, anger, disgust, contempt, and fear are negative emotions and surprise and happiness are classified as positive.

From the above studies, and due to the nuances of the Vietnamese language, one or more sounds may translate into one English word. For example, the word "beautiful" in English can be written simply as “đẹp," but "orphan" in English is written "mồ côi," which is a combination of two sounds; "illiterate" can be written as "không biết đọc, biết viết" or "mù chữ" in Vietnamese, which is a combination of multiple sounds. A sound in Vietnamese appears in a form of word in English, but it may or may not have any meaning. Therefore, this study's researchers measured emotional language by using emotional phrases as the unit of analysis. The number of phrases was compared to the total number of words in the article to determine an overall ratio of emotional language. This helped account for different article lengths.

Emotional language in this study was defined as any of the following: (1) a phrase that was negative in nature and tone that leads readers to think about the loss of significant other(s) and right(s) in the context that if the loss would not have happened, there would be a better future for the character. For instance, phrases related to significant loss might involve (1) the story of a student who was about to drop out of school after the death of her father; (2) a phrase that led readers to think about what was lacking or missing by emphasizing the word "no" or "absent." Stories could be classified in this category if they had phrases that showed the character had no financial source, no opportunities, and had not yet met basic needs or if it contained straightforward words such as poor or hopeless. An example of a negative word "no" was found in the study pretest in an article titled "No father, no mother, and no house," which featured two 
young orphaned students who lived under the heavy pressure of financial needs just to finish high school; (3) a phrase that arouses sadness or pity feelings such that there was little or no hope for the featured subjects to escape poverty or reach their goals because they are so small in power and social status or their past and present efforts did not change their poor lives. An example of this could be seen though the story of a poor, hard-working mother who could not afford money for her cancer treatments and could barely feed her three young children; (4) a phrase featuring the subjects as those who held overwhelming jobs, found for examples in the story of (a) an 11-year-old girl who was head of the family and worked to feed three siblings while her father is irresponsible (b) a woman who was abused by her husband. She worked to feed the family while her irresponsible husband had a mistress. In short, emotional language was defined as being negative in nature or tone or language that arouses anger, pity, empathy, sympathy, sorrow, and/or hopelessness in the readers toward the characters.

Demographics of featured subjects were broken down into variability of gender

(female: 1, male: 0), social ethnics (Vietnamese: 0, Minority groups: 1), age (under 22: 0, from 22 to under 60: 1, 60 and older: 2), marriage status (0: not applicable, 1: still have spouse, 2: widowed, divorced or single parent), and location (1: rural areas, 2: big city). Lundman (2003) was one of many researchers who employed this basic demographic variability in his study.

This study's researcher took the grounded approach to address the severity themes that the journalists used as details for their episodic frames. The themes arose from the articles themselves. Mastin, Choi, Barboza and Post (2007) also used this strategy to content analyze framing of elder abuse in newspapers. 
The unit of analysis was the newspaper article. Nearly 13 percent of the total stories $(\mathrm{N}=5)$ were pretested for this study to test the coding sheet and to identify initial episodic frames. Episodic frames that arose from the pretest stories included the following: (1) the subject has health problems and could not afford health care or carry out his/her hard work load; (2) the subject was too young to work as an adult (subject is at school age by the time he or she must by necessity take responsibility); (3) the subject's future was uncertain, such as a school drop-out risk or has lost his or her parents, guardian; (4) the subject had a heavy burden due to his/her responsibility to take care of others and (5) and other severity themes with less frequency that might arise while coding were noted. Every theme was coded as Present (1) and Absent (0). Appendix A contains the study's coding sheet.

The number of emotional phrases and the number of episodic severity frames or themes were counted in each story and compared to the amount of money raised from each newspaper article. The demographics of each featured subject and the amount of money raised also were explored. The most commonly used and most effective frames or themes in terms of money raised are discussed in the discussion section.

However, it is important to reiterate that multiple factors could influence an individual's decision to donate money. The severity themes applied in this study were only the manifest content from the perspective of the researcher and second coder. The reader's context is always larger than a single article. The researcher did not attempt to make any claims about the article being solely responsible for the donation made.

Initially, a five-point emotional Likert scale created from a study by Haider Markel (2006) and Kingori (2004) was pre-tested. However, after the pretests, the coders 
decided to simply count the number of emotional phrases because with the five-point scale, all stories had very high scores and thus little variability.

A Vietnamese researcher and scientist who agreed to help with this study independently coded 23 percent $(\mathrm{N}=9)$ randomly selected stories. An intercoder reliability test for simple agreement and agreement by change (Holsti formula) was conducted with the second coder. His coding was compared to the author's using Holsti's formula to assess intercoder reliability (Wimmer \& Dominick, 2006). The Holsti average was .82, which is acceptable (Neuendorf, 2007).

Data of donations in 2009 and January 2010 were updated frequently on the Sai Gon Tiep Thi newspaper website, clearly stating who (individual or company) donated how much when (dd/mm/yyyy) for whom (specific featured subjects or for the campaign in general). This study also examined the type of donor. One featured subject may have received a very large donation from one donor while others may have spurred many more but smaller amounts. The sequence of donation may affect who gets donation. Types of donors were coded as individual (1) and company (2). As this campaign lasted for one year, stories published earlier may have had longer to raise money than stories published in the end of 2009. Therefore in this study, donations were counted for only a one month period (30 days) for every story. Donations that came in on the 31st day and after were not calculated. Donation data was calculated after the coding process was finished to avoid any undue coder influence.

To test the hypotheses, this study employs the Statistical Package for the Social Sciences (SPSS) 17.0 to analyze the variances. One way analysis of variance (ANOVA), which is applied for three or more levels of independent variables was used with 
Bonferroni Post Hoc test to correct for Type I error, when we believe there is an effect and there is not, by counting for multiple tests at once. Also, independent t-tests and Pearson $r$ correlations statistical test (Salkind, 2004) were used to test the relationship and correlation of variance. A statistics graduate assistant helped with the analysis.

\section{Findings}

This exploratory study attempted to find whether emotional phrases in episodically framed stories in a Vietnamese column was related to the money raised. It also looked at the severity themes used in each episodic story to explore whether themes had a possible impact on donation.

The first research question asked about the demographics of financially disadvantaged people featured in Sai Gon Tiep Thi newspaper. This study looked at the demographic variables of age, gender, location, social ethnicity, and marriage status of the featured subjects. Statistical tests of one-way ANOVA was employed to analyze the relationship among age and marriage status and one month donations raised, while independent $\mathrm{T}$-tests were employed to analyze the relationship between gender, location and social ethnicity with one month donations raised. There is not a significant relationship between any of the demographic variables and money raised $(F(2,36)=$ $.651, p>.05),(t(37)=0.443, p>.05),(t(37)=-1.246, p>.05)$ and $(F(2,36)=3.09, p>.05)$ (see Tables 1, 2, 3 and 4) with one exception: ethnicity $(t(37)=-2.258, p<.05)$ (see Table 5). The variable marriage approached significance $(p=.058)$ in terms of being a significant factor in money raised. 
Table 1. ANOVA result for relationship between age and money raised

\begin{tabular}{|l|r|r|r|r|r|}
\hline & Sum of Squares & df & Mean Square & \multicolumn{1}{|c|}{ F } & Sig. \\
\hline Between Groups & $4.687 \mathrm{E} 13$ & 2 & $2.344 \mathrm{E} 13$ & .651 & .528 \\
Within Groups & $1.297 \mathrm{E} 15$ & 36 & $3.602 \mathrm{E} 13$ & & \\
Total & $1.344 \mathrm{E} 15$ & 38 & & & \\
\hline$p<.05$ & & & \\
\hline
\end{tabular}

Table 2. Independent t-test result for relationship of gender and money raised

\begin{tabular}{|l|l|l|l|l|r|r|}
\hline \multirow{2}{*}{ One_month_donation } & & $\mathrm{F}$ & $\mathrm{Sig}$. & $\mathrm{t}$ & $\mathrm{df}$ & $\mathrm{p}$ \\
& $\begin{array}{l}\text { Equal } \\
\text { variances } \\
\text { assumed }\end{array}$ & 0.653 & 0.424 & 0.443 & 37 & 0.66 \\
\cline { 2 - 6 } & $\begin{array}{l}\text { Equal } \\
\text { variances } \\
\text { not } \\
\text { assumed }\end{array}$ & & & 0.414 & 18.241 & 0.684 \\
\hline \begin{tabular}{l}
$p<.05$ \\
\hline
\end{tabular}
\end{tabular}

Table 3. Relationship of location (rural and big city) and money raised

\begin{tabular}{|l|l|c|r|r|r|r|}
\hline & & $\mathrm{F}$ & $\mathrm{Sig}$. & $\mathrm{t}$ & $\mathrm{df}$ & $\mathrm{p}$ \\
\hline $\begin{array}{l}\text { One_month_donation } \\
\text { Equal variances } \\
\text { assumed }\end{array}$ & 10.425 & .003 & -1.626 & 37 & .112 \\
\cline { 2 - 6 } & $\begin{array}{l}\text { Equal variances not } \\
\text { assumed }\end{array}$ & & & -1.246 & 13.832 & .233 \\
\hline
\end{tabular}


Table 4. ANOVA result for relationship between marriage status and money raised One_month_donation

\begin{tabular}{|l|r|r|r|r|r|}
\hline & Sum of Squares & df & Mean Square & \multicolumn{1}{c|}{ F } & Sig. \\
\hline Between Groups & $1.969 \mathrm{E} 14$ & 2 & $9.846 \mathrm{E} 13$ & 3.091 & .058 \\
Within Groups & $1.147 \mathrm{E} 15$ & 36 & $3.185 \mathrm{E} 13$ & & \\
Total & $1.344 \mathrm{E} 15$ & 38 & & & \\
\hline$p<.05$ & & & & \\
\hline
\end{tabular}

Independent $\mathrm{t}$-tests found that there is a significant relationship between the ethnicity of the featured subject and money raised $(t(37)=-4.193, p<.05)$ as indicated in Table 5. This means that significantly more money was raised for minorities, which made up 2.6 percent of the article subjects overall.

Table 5. Independent t-test result for relationship of social ethnicity and money raised

\begin{tabular}{|l|l|l|l|l|l|r|}
\hline & & $\mathrm{F}$ & $\mathrm{Sig}$. & $\mathrm{t}$ & $\mathrm{df}$ & \multicolumn{1}{c|}{$\mathrm{p}$} \\
\hline $\begin{array}{l}\text { One_month_donation } \\
\text { Equal variances } \\
\text { assumed }\end{array}$ & & & -4.193 & 37 & .000 \\
\cline { 2 - 6 } & $\begin{array}{l}\text { Equal variances } \\
\text { not assumed }\end{array}$ & & & & $\cdot$ & $\cdot$ \\
\hline
\end{tabular}

The first hypothesis predicted a correlation between emotional phrases and money raised. The hypothesis stated a positive prediction about this correlation, meaning the more emotional phrases used in the story would result in more donations. Pearson correlation statistic was used to test this hypothesis $(r(37)=.605, p<.01)$. There is a positive moderate to slightly strong relationship between the sheer number of emotional 
phrases and money raised. The two variables share 37 percent of the coefficient $\left(r^{2}=.37\right)$ (see Table 6) meaning that 37 percent of this donation variance can be explained by the number of emotional phrases.

Table 6. Pearson correlation between emotional phrases in the story and money raised.

\begin{tabular}{|c|c|c|c|}
\hline & & One_month_donation & Emotional_phrases \\
\hline \multicolumn{2}{|c|}{ One_month_donation Pearson Correlation } & 1 & $.605^{* *}$ \\
\hline & Sig. (1-tailed) & & .000 \\
\hline & $\mathrm{N}$ & 39 & 39 \\
\hline \multirow[t]{3}{*}{ Emotional_phrases } & Pearson Correlation & $.605^{* *}$ & 1 \\
\hline & Sig. (1-tailed) & .000 & \\
\hline & $\mathrm{N}$ & 39 & 39 \\
\hline
\end{tabular}

The relationship between the ratio of emotional phrases and money raised was also tested with the Pearson correlation statistic to examine if the higher the ratio of emotional phrases to words positively correlated with money raised. There is a moderate relationship between ratio of emotional phrases to total words in the article with money raised $(r(37)=.892, p<.01)$. The two variables share 29 percent of the coefficient $\left(r^{2}\right.$ $=.29)$ (see Table 7). 
Table 7. Pearson correlation between ratio of emotional phrases to words of story and money raised.

\begin{tabular}{|ll|r|r|}
\hline & & Emotional_phrases & Ratio_of_EP_W \\
\hline Emotional_phrases & Pearson Correlation & 1 & $.892^{* *}$ \\
& Sig. (1-tailed) & 39 & .000 \\
& $\mathrm{~N}$ & $.892^{* *}$ & 39 \\
\hline Ratio_of_EP_W & Pearson Correlation & .000 & 1 \\
& Sig. (1-tailed) & 39 & 39 \\
& $\mathrm{~N}$ & & \\
\hline$p<.01$ & & & \\
\hline
\end{tabular}

These two findings supported hypothesis 1 . There is a positive correlation between the use of emotional phrases and money raised.

The second hypothesis predicted the more episodic, severity frames used, the more money would be raised for the featured subject. Again, the Pearson correlation statistic test was used to test if more severity themes resulted in more money raised while an Independent t-test was used to examine the relationship of each single theme with the money raised. This hypothesis was not supported (see Table 8).

\begin{tabular}{|c|c|c|c|}
\hline & & Present_themes & One_month_donation \\
\hline \multirow[t]{3}{*}{ Present_themes } & Pearson Correlation & 1 & .223 \\
\hline & Sig. (1-tailed) & & .086 \\
\hline & $\mathrm{N}$ & 39 & 39 \\
\hline \multirow[t]{3}{*}{ One_month_donation } & Pearson Correlation & .223 & 1 \\
\hline & Sig. (1-tailed) & .086 & \\
\hline & $\mathrm{N}$ & 39 & 39 \\
\hline
\end{tabular}


There was not a significant correlation between the number of severity themes and the amount of donations $(r(37)=.223, p>.01)$. In other words, more severity themes did not relate to more money raised. Simple statistics were used to examine these "frequencies." Among the five themes that rose from the stories, "subjects had uncertain lives" was the most frequent theme, present in 92.3 percent of the stories. The next most frequent themes in descending order were "heavy burden," "health problem," "child labor" and "others."

This study also examined the variable of visuals used along with the story, such as who was portrayed in the photograph, where it was taken and how it appeared. One-way ANOVA was employed to test the relationship of photograph content and money raised and Pearson correlation was used to test the correlation between number of photographs in the story and money raised. There is not a significant relationship between the number of photographs and donations in total $(r(37)=-.065, p>.01)$. There was not a significant effect of the location of the photograph and money raised $(F(2,36)=.660, p>.05)$. Also there was not a significant effect of who was portrayed (themselves, with significant others or their significant other only) $(F(2,36)=1.41, p>.05)$. The tones of the photo (neutral, positive, negative) was not significant in terms of money raised $(F(2,36)=.62$, $p>.05$ ). From the census of photographs in Vuot Len So Phan series, the photographs did not as telling as the episodic frames in the stories.

Even though this study did not ask questions about donors (company or individual), the donor was analyzed to find whether company donors tend to give more money than individual donors. Overall, the money raised ranged from 20,500,000 (2.6 percent) Vietnamdong to 300,000 Vietnamdong (5.1 percent). Company donors tended to 
give more money on average than individual ones, however, collectively this group did not donate more: only 7 percent (8) of company donors gave 31 percent (35400000) of the total money raised. Most of the subjects received money from many small individual donations.

\section{Discussion}

This exploratory study selected one column of a Vietnamese newspaper to examine the relationship of emotional phrases and severity themes used with the amount of money raised.

Only the hypothesis about the correlation between the more emotional phrases used, the more money raised was supported. There could be many reasons a person donated money to a featured subject. Using the guidelines in the codebooks, the story of a widow who had active cancer with three dependent children was considered one of the stories with the highest emotional phrases. It seemed that the length of the story did not have a significant role in raised money $(r(37)=.158, p<.05)$. Although this was only a post hoc test, the findings go against Mebane (2001), who claims article length can influence public attitudes.

The demographics (gender, age, location and ethnicity) of featured subjects were not significantly correlated to the amount of money raised. However, only about one third of the featured subjects were male. This was consistent with Giang and Pfau's (2009) findings in a study about ageing, poverty and the role of a social pension in Vietnam. They found that elderly female were more prevalent and experienced a higher poverty rate than their male counterparts. Although this study found there was no significant relationship between subject's age and money raised, it was important to notice that all 
the featured subjects were either under 22 or had dependents (children or grandchildren) who were under 22 years old. It could be that the donations sent to the featured subjects who were above 22 were meant to help their dependents with some financial resources to continue schooling, for Vietnamese people believe this can help them escape from poverty.

This study found that nearly two-thirds of the featured subjects were living in the rural area. This was consistent with Giang and Pfau's (2009) findings. They found that more than 70 percent of the elderly poor were living in the rice-producing regions in Vietnam. For featured subjects living in big cities, many of them were originally from rural areas and immigrated to the city with hope that they could have a job and earn enough money for the family.

Although this study found that ethnicity was significantly related to money raised, this result might have happened by chance. There was only one person from a minority group, making up 3 percent of the sample and therefore, the findings reliable. Khmer, the featured subject's ethnicity was counted for 1.4 percent of the population (CIA, 2010). This researcher also noted that the founder of Vuot Len So Phan, who is also a celebrity journalist in Vietnam, wrote the story about this widowed, Khmer man. This was the only story by this celebrity writer for this column, so his name could have influenced greater donations (Vo, personal communication, August 10, 2009).

The featured subjects who received higher donations than others were young orphaned students; sick and widowed with young children; a mother with cancer who suffered great gender inequality and an ethnic widowed man with three young children. 
Among the five themes representing the hardship of the featured subjects tested in the second hypothesis, some themes presented more often than others. For example, "uncertain life" appeared in 92.3 percent of the stories and only three stories did not contain this theme. Therefore, due to the small sample size, the variance ratio of "Present" and "None" in each theme is not equal and this affected the statistical output. From the coding process, this study noted that each story situation was unique. For instance, "Ngôi nhà của người mẹ ung thư" was a story that featured an active cancer widow with three dependants, and it attracted more donations than "Cô bé 11 tuổi thay cha mẹ nuôi đàn em," a story of an 11-year-old girl who was responsible for three other siblings. The hardship in the first story was understood as a current or an on-going issue. On the other hand, the hardship in the second story seemed more severe, but it was understood as things that happened in the past because, at least in the recent years, the featured subjects in the story had a pretty stable life. More important, "Ngôi nhà của người mẹ ung thư" was the first story of the column while "Cô bé 11 tuổi thay cha mẹ nuôi đàn em" ran months after that. The first story might have received more promotion and therefore more support than the second story.

To see if donations tended to decrease over time, the census of 39 stories was divided into two chronological groups to compare the sum of donations of the first and second half groups. The first group included 19 stories. The second group included 20 stories. The first 19 stories received 94,250,000 million Vietnam dong in total (81.5 percent) while the 20 other stories received 21,270,000 (18.5 percent) million Vietnam dong out of $116,000,000$ Vietnamdong. This fact showed that, the earlier the story came out, the more likely it was to receive more donations. There could be many different 
reasons influencing this fact. Maybe the readers made many donations at first and in the end they ran out of money to give. Maybe they were tired of reading so many sad stories and avoided them.

To understand a little better about the declining of donations for the latter group and the success of the earlier group, this study applied statistical tests to compare the first and second group. For the second group, it was interesting to see who received more donations and what these people shared in common. Stories in the second group had fewer emotional phrases overall than in the first group. There was not a correlation between emotional phrases and money raised in the second group of stories. As in the general test, age, gender, and marriage status did not have a significant relationship with money raised; however, in the second group, location was found significant $(t$ (18) $=3.214, p<.05$ ). There was only one subject who was minority and this story was in the first group.

The appearance of photographs did not significantly relate to money raised. Stories with two photos, however, were likely to attract more donations than those with only one photo. There was a slightly strong, positive correlation between the number of photographs used and money raised in the second group with 42 percent of the coefficient $(r(18)=.650, p<.01)$. Owing to the small variance, it seemed unlikely that photographs used had any effect on the money raised. This finding was not supported Goldberg (1991) and Coleman (2006). However, this did not mean that visuals were not the important factors for Vuot Len So Phan column because this study was unable to address the effects of video and judging news photos was subjective and based on individual bias (Bissell, 2000). 
Two-thirds of the stories ( $\mathrm{N}=29)$ had one only photo and the rest of the stories used just two photos. The photos seemed to give the readers a general idea about the featured subjects. They were more or less a claim of the writers: The featured subjects existed. Many of the photographs were portraits and therefore, the readers barely got any additional background information (see Appendix C). From the photographs only, it was difficult to tell if the featured subjects came from poor families that needed immediate help. These photographs mainly illustrated certain details in the story or captured one particular moment, such as the featured subjects sold lottery tickets on the street, had injuries, or went to school. Most of the pictures in this column seemed to have been taken by the journalists, and not by a professional photojournalist, who might have captured better quality photographs. Therefore, in general, the photos were not very emotionally captivating as they usually were in Western countries. There was even a photo of the featured subject being interviewed with the anchor for the TV program. Overall, the photographs in Vuot Len So Phan column were not as telling as the stories. However, this study did not attempt to make any claims about the quality of the photographs.

There was also a strong positive correlation between the number of donors and money raised $(r(18)=.894, p<.01)$. In the census, company donors gave more than 30 percent; in the second group, company donors were not significant in terms of money raised. In the second group of stories, only one company donor ( 2 percent) donated 1,000,000 million Vietnamdong ( 5 percent) while the rest of the 98 percent came from individual donors.

There were 122 donors total $(\mathrm{N}=122)$ and individual donors (114) were significantly different from company donors (8). The companies tended to contribute 
larger amounts in the early stories compared to the much larger population of individual donors.

\section{Limitations}

Several limitations to this study need to be highlighted. First and foremost, this study could not determine whether the donors were influenced primarily by the emotional language used in the newspaper stories or by other factors, such as the TV broadcast, personal experience or empathy regarding particular subjects. Also, it seems as if there was a diminishing donation factor, or a "compassion fatigue" factor (Figley, 1999, p. 10). Compassion is both the capacity and the interest of caring (Figley, 2008). "Compassion fatigue" is the natural, declining consequence of behaviors and emotions resulting over time from knowledge about a traumatizing event experience by others (Figley, 1999). Hyman (2004) found a negative correlation between the length of time that a worker has been exposed to traumatic material and their caring for others.

Of course, multiple factors go into a person's desire to donate that a content analysis cannot account for. Therefore, no claim can be made about the article being responsible for the money raised. Although two coders were involved in this study and intercoder reliability was acceptable, emotional elements of articles are subjective. From the content of five stories that received the highest donations, there were signs of "deserving poor" in three stories, which was consistent with Gans' study (1995).

Although more than 90 percent of the stories had subjects with grave financial or health issues, there were cases where the featured subjects suffered great injustices that this study did not take into account or code. 
Also, this study captured one short period of time. There were a few cases in which the featured subjects' dependents were offered scholarships to university, received some stipend consecutively every month or received health treatment. This study did not count these donations or other donations that came after one month or that may have gone directly to the individual, bypassing the newspaper.

\section{Future research implications}

Future research on this topic should include larger samples in longer time frames and consider multiple effects of different mediums that might attract people to donate, e.g., website, print newspaper, broadcasting or other media types. The effect of visuals such as photographs and video should be examined more independently and thoroughly. Expanding the time period in future studies would yield new findings because featured subjects may have received multiple donations over time, so in the end, their donations would be higher. However, it could also show that the majority of donations received can be expected soon after stories appears, with a diminishing return after a certain time frame. There is also the need to consider other framing factors such as deserving level and injustice.

Additionally, it would be beneficial to assess giving from the reader's view by conducting interviews or surveys with people who donate, for example.

For fund raising purposes, future studies should consider the degree of awareness activities and other promotional efforts applied to further explore the diminishing of donations as time goes on. It could be the newspaper did not remind the reader as often as they should or maybe "compassion fatigue" or lack of resources occurred over time. Future researches could examine whether there is an optimal number of stories to raise 
money more efficiently. Additional research could examine other cultures and other international perspectives regarding journalism's role in philanthropy. 


\section{References}

Andreoni, J. (1998). Toward A Theory Of Charitable Fund Raising. The Journal of Political Economy, 106(6), 1186-1213.

Barnett, A., Hodgetts, D., Nikora, L., Chamberlain, K., \& Karapu, R. (2007). Child Poverty And Government Policy: The Contesting Of Symbolic Power In Newspaper Constructions Of Families In Need. Journal of Community \& Applied Social Psychology 17, 296-312.

Barrett, A. W., \& Barrington, L. W. (2005). Is A Picture Worth A Thousand Words?: Newspaper Photographs And Voter Evaluations Of Political Candidates. The Harvard International Journal of Press/Politics, 10(4), 98-113.

Barry, A. M. (1997) Visual Intelligence: Perception, Image, and Manipulation in Visual Communication. New York: State University of New York Press.

Benford, R., \& Snow, D. (2000). Framing Processes And Social Movements: An overview and Assessment. Annual Review of Sociology, 26(1), 611-639. http://search.ebscohost.com

Berger, A. A. (2000). Media and Communication Research Methods: An Introduction to Qualitative and Quantitative Approaches. London: Sage publications.

Besemeres, M. (2004). Different Languages, Different Emotions? Perspectives from Autobiographical Literature. Journal of Multilingual and Multicultural Development, 25(2\&3), 140-158.

Bissell, K. (2000). Culture and Gender as Factors in Photojournalism Gatekeeping. Visual Communication Quarterly, 7, 9-12.

Brewer, P. R. (2001). Value Words And Lizard Brains: Do Citizens Deliberate About Appeals To Their Core Value? Political Psychology, 22, 45-64.

Central Intelligence Agency. (2010). Vietnam. Retrieved April 2010, 2010, from https://www.cia.gov/library/publications/the-world-factbook/geos/vm.html

Chong, D. (1996). Values Versus Interests In The Explanation Of Social Conflict, University of Pennsylvania Law Review, 144, 2079-2134.

Clawsone, R. A., \& Trice, R. (2000). Poverty As We Know It: Media Portrayals Of The Poor. The Public Opinion Quarterly, 64(1), 53-64.

Coleman, R. (2006). The Effects Of Visuals On Ethical Reasoning: What's A Photograph Worth To Journalists Making Moral Decisions? Journalism \& Mass Communication Quarterly, 83(4), 835-850. Retrieved from Academic Search Complete database. 
Damasio, A. (1994). Descartes' Error: Emotion, Reason, And The Human Brain. Putnam.

Entman, R. M. (1993). Framing: Toward Clarification Of A Fractured Paradigm. Journal of Communication, 43(4), 51-58.

Evan. M., \& Harkness, S. (2008). Elderly People In Vietnam: Social Protection Informal Support And Poverty. The Policy Press, 16(3), 245-253.

Felicia, M. (2001). "Want To Understand How Americans Viewed Long-term Care In 1998? Start with Media Coverage." The Gerontologist, 41, 24-33.

Figley, C. F., \& Stamm, B. H. (1996). Psychometric Review of Compassion Fatigue Self Test. Measurement of stress, trauma, and adaptation. Lutherville, MD: Sidran Press.

Fliert, E. V. D., \& Do, T. M. H. (2009). Communication for Development: Targetting the Untargetted. Media Development.

Franklin. D. G., \& Iyengar, S. (2000). "Prime Suspects: The Influence of Local Television News on the Viewing Public." American Journal of Political Science 44,560-73.

Gans, H. J. (1995). The War Against The Poor: The Underclass And Antipoverty Policy. New York: A Division of Harper Collins Publishers Inc.

General Statistical Office (2001): Vietnam 1975-2000. Hanoi: Statistical Publishing House.

Giang, T.L, \& Pfau, W.D., (2009). Ageing, Poverty And The Role Of A Social Pension In Vietnam. Development and Change, 40(2), 333-360.

Gilens, M. (1996). Race And Poverty In America: Public Misperceptions And The American News Media. The Public Opinion Quarterly, 60(4), 515-541.

Gilliam, F. D., Jr., Valentino, N. A., \& Beckmann, M. N. (2002). Where You Live And What You Watch: The Impact of Racial Proximity And Local Television News On Attitudes About Race And Crime. Political Research Quarterly, 55, 575-780.

Goldberg, V. (1991). The Power Of Photography: How Photographs Changed Our Lives. New York: Abbeville Publishing Group.

Goldie, P. (1999). How We Think Of Others' Emotions. Mind \& Language, 14(4), 377. Retrieved from Academic Search Complete database.

Golding, P., \& Middleton, S. (1982). Images Of Welfare: Press and Public Attitudes To Poverty. Oxford: Martin Robertson. 
Gross, K. (2008). Framing Persuasive Appeals: Episodic And Thematic Framing, Emotional Response, and Policy Opinion. International Society of Political Psychology, 29(2), 169-192.

Gross, K., \& D'Ambrosio, L. (2004). Framing Emotional Response. Political Psychology, 25(1), 1-29. doi:10.1111/j.1467-9221.2004.00354.x.

Grunig, S. D., (1995). The Impact Of Development Office Structure on Fund-Raising Efficiency For Research and Doctoral Institutions. The Journal of Higher education, 66(6), 686-699. http://www.jstor.ord/stable/2943836.

Hà-Anh. (2009). Hạn Chế Việc Báo Chí Sử Dụng Ngân Sách. Retrieved October 18, 2009, from http://www.nghean.gov.vn/adnews/default.asp?m=20\&act=view\&id=918\&p=15

Haider-Markel, D., Allen, M., \& Johansen, M. . (2006). Understanding Variations In Media Coverage Of U.S. Supreme Court Decisions: Comparing Media Outlets In Their Coverage of Lawrence. Texas. Harvard International Journal of Press/Politics, 11(2), 64-85. doi:10.1177/1081180X05286065

H-Dieu. (2010). Ban Từ Thiện Xã Hội Báo Giác Ngộ Tổng Kết Hoạt Động Năm 2009. Retrieved Febuary 27, 2010, from http://www.giacngo.vn/xahoi/2010/01/26/5B4049/

Hodgetts, D., Cullen, A., \& Radley, A. (2005). Television Characterizations Of Homeless People In The United Kingdom. Analyses of Social Issues \& Public Policy, 5(1), 29-48. doi:10.1111/j.1530-2415.2005.00054.x.

Hodgetts, D., Hodgetts, A., \& Radley, A. (2006). Life In The Shadow Of The Media. European Journal of Cultural Studies, 9(4), p.497-516.

Hodgetts, D., Masters, B., \& Robertson, N. (2004). Media Coverage Of 'Decades Of Disparity' In Ethnic Mortality In Aotearoa. Journal of Community \& Applied Social Psychology, 2004, 14(6), 455-472.

Hyman, O (2004). Perceived Social Support And Secondary Traumatic Stress Symptoms In Emergency Responders. Journal of Traumatic Stress, 17, 149-156.

Internet enemy. (2009). Paris: Reporters without borders.

Iyengar, S. (1991). Is Anyone Responsible? How television Frames Political Issues. Chicago: The University of Chicago Press.

Iyengar, S.,\& Kinder, D. R. (1987). News That Matter: Television And American Opinion. Chicago: University of Chicago Press. 
Jones, R. S., Hopkins, A. H., (1985). State Campaign Fund Raising: Targets And Response. The Journal of Politics, 7(2), 427-449. http://www.jstor.org/stable/2130890.

Kelly, K. S. (1991). Fund Raising and Public Relation: A critical analysis. London: Publishers Hillsdale.

'Không Cho Phép Báo Chí Tư Nhân.' (2008). Retrieved October 18, 2009, from http://www.bbc.co.uk/vietnamese/vietnam/story/2008/07/080717_press_law.shtm 1

Kinder, D. R., \& Sanders, L.M. (1990). Mimicking Political Debate With Survey Questions: The Case of White Opinion On Affirmative Action For Blacks. Social Cognition, 8, 73-103.

Kingori, P., Wellings, K., French, R., Kane, R., Gerressu, M., \& Stephenson, J. . (2004). Sex And Relationship Education And The Media: An Analysis Of National And Regional Newspaper Coverage In England. Sex Education, 4(2), 111-124. Retrieved from Academic Search Complete database

Lam-Điền. (2005). Gia Định Báo: Những Giá Trị Vẫn Còn Sau 140 Năm. Retrieved from http://www.tuoitre.com.vn/tianyon/Index.aspx?ArticleID=115339\&ChannelID $=1$ $\underline{0}$

Lundman, R. J. (2003). The Newsworthiness And Selection Bias In News About Murder: Comparative And Relative Effects Of The Novelty And Race And Gender Typifications On Newspaper Coverage Of Homicide. Sociological Forum, 18(3), 357-386.

Mặc-Lâm. (2009). Nhà Báo Võ Đắc Danh Và Loạt Phim Tài Liệu Ký Sự "Vượt Lên Số Phận”. Retrieved April 11 from http://www.rfa.org/vietnamese/programs/LiteratureAndArts/Friendly-chat-withwriter-vo-dac-danh-about-his-series-short-films-overcome-the-destiny-mlam$\underline{08222009130155 . h t m l}$

Mastin, T., Choi, J., Barboza, G. E., \& Post, L. (2007). Newspapers' Framing Of Elder Abuse: It's Not A Family Affair. Journalism \& Mass Communication Quarterly, 84(4), 777-794. Retrieved from Academic Search Complete database.

Minot, N., \& Baulch, B. (2005). Spatial Pattern Of Poverty In Vietnam And Their Implications For Policy. International Food Research Institute, 30, 461-475.

Minot, N., \& Goletti, F. (1998). Export Liberalization And Household Welfare: The Case Of Rice in Vietnam. American Journal of Agricultural Economics, 80(4), 738749. Retrieved from http://www.jstor.org/stable/1244060 
Myhre. S. L., Saphir, M. N., Flora, J. A. Howard, K. A., Gonzalez, E. M., (2002). Alcohol Coverage In California Newspapers: Frequency, Prominence, And Framing. Journal of Public Health Policy, 23(2), 172-190.

Nabi, R. L. (2003). Exploring The Framing Effects Of Emotion: Do Discrete Emotions Differentially Influence Information Accessibility, Information Seeking, And Policy Preference? Communicate Research, 30, 224-247. Doi: 10.1177/0093650202250881.

Nelson, T. E., \& Kinder, D. R. (1996). Issue Framing And Group-Centrism In American Public Opinion. Journal of Politics, 58, 1055-1078.

Neuendorf, K. (2007). The Content Analysis Guidebook. California: Thousand Oaks Sage Publications

Oxburgh, G., Williamson, T., \& Ost J. (2006). Police Officers Use Of Emotional Language During Child Sexual Abuse Investigations. Journal of Investigative Psychology and Offenders Profiling, 3, 35-45.

Phuc-Dien. (2010). Ngày Mai Khai Mạc Ngày Hội Tư Vấn Tuyển Sinh - Hướng Nghiệp. Retrieved February 26, 2010, from http://www3.tuoitre.com.vn/TuyenSinh/Index.aspx?ArticleID=365381\&ChannelI $\mathrm{D}=142$

Pingali, P. L., \& Vo-Tong, X. (1992). Vietnam: Decollectivization And Rice Productivity Growth. Economic Development and Cultural Change, 40(4), 697-718

Riffe, D., Aust, C. F., \& Lacy, S. R. (1993). The Effectiveness Of Random, Consecutive Day and Constructed week samplying in Newspaper Content Analysis. Journalism Quarterly, 70(1), 133-139.

Salkind, N. J. (2004). Statistics For People Who (Think They) Hatee Statistic. California: Thousand Oaks Sage Publications.

Schiller, B. R. (1989). The Economics Of Poverty And Discrimination (5th ed.). New Jersey: Prentice Hall.

Seelig, M. (2000). A Case For The Visual Elite. Visual Communication Quarterly, 12, 164-181.

Snow, D.A. \& Benford, R.D. (1988). Ideology, Frame Resonance, And Participant mobilization. International Social Movements Research, 1, 197-218.

Sunstein, C. R. (2005). Moral Heuristics. Behavioral And Brain Sciences, 28, p.531-537.

Tenenbaum, D. (1996). The Value Of Vietnam. Environmental Health Perspectives, 104(12), 1280-1285. http://search.ebscohost.com.www.libproxy.wvu.edu, doi:10.2190/TW.37.3. 
Thailand Retains World's Largest Rice Exporter. (2006). Retrieved October 18, 2009, from http://english.people.com.cn/200604/25/eng20060425 260937.html

Thang, N.M., \& Popkin. B.M. (2004). Patterns Of Food Consumption In Vietnam: Effects On Socioeconomic Groups During An Era Of Economic Growth. European Journal of Clinical Nutrition, 58, 145-153.

Thanh-Hoang. (2007). Những Cái Nhất Của Báo Chí Việt Nam. Retrieved April 3, 2010, from http://vietbao.vn/Xa-hoi/Nhung-cai-nhat-cua-bao-chi-Viet$\mathrm{Nam} / 30184222 / 157 /$

Thayer, A., Evans, M., McBride, A., Queen, M., \& Spyridakis, J. (2007). Content Analysis As A Best Practice In Technical Communication Research. Journal of Technical Writing \& Communication, 37(3), 267-279.

Tra-Giang. (2008). "Độc Quyền” Làm Từ Thiện, Lợi Hay Hại? Retrieved February 27, 2010, from http://phapluattp.vn/237195p0c1013/doc-quyen-lam-tu-thien-loi-hayhai.htm

Việt Nam Là Một Nước Hàng Đầu Về Xuất Khẩu Gạo. (2006). Retrieved October 18, 2009, from http://vietbao.vn/Kinh-te/Viet-Nam-la-mot-nuoc-hang-dau-ve-xuatkhau-gao/55108852/93/

Vietnam. (n.d). Retrieved April 3, 2010, from http://www.ausaid.gov.au/country/country.cfm?CountryID=33

Vietnamjournalism. (2004). Báo Chí Việt Nam Và Cái Thuở Ban Đầu... Retrieved April 3,2010 , from http://www.vietnamjournalism.com/index.php?option=com_content\&view=articl e\&id=100:website-vit-cha-th-t-pha-v-qung-cao\&catid=30:bao-dientu\&Itemid $=94$

Việt-Văn. (2008). Nhà Báo Phải Hiểu Chỗ Đứng Của Mình. Retrieved October 18, 2009, from http://www.laodong.com.vn/Home/Nha-bao-phai-hieu-cho-dung-cuaminh/20086/94139.1aodong

Vo, D. D. (2009, 10/13). 52 Câu Chuyện Tử Tế. Sai Gon Tiep Thi. Retrieved October 18, 2009, from http://www.sgtt.com.vn/Detai196.aspx?ColumnId=96\&NewsId=49161\&fld=HTM $\underline{\mathrm{G} \backslash 2009 \backslash 0331 \backslash 49161 .}$

Wimmer, R.D., \& Dominick, J. R. (2006). Mass Media Research: An Introduction. United States: Thomson Wadsworth.

Wolman, R. N., Lewis, W. C., King, M. (1971). The Development Of The Language Of Emotions: Conditions Of Emotional Arousal. Child Development, 42, 1288-1293. 
World Rice Exports. Retrieved October 18, 2009, from http://www.thailand.com/exports/html/industry_worldriceexport.htm

World-Bank. (2008). Fact Sheet: Sustaining And Broadening The Growth Momentum. Retrieved April 3, 2010, from http://web.worldbank.org/WBSITE/EXTERNAL/EXTDEC/EXTGLOBALMONI TOR/EXTGLOMONREP2008/0, contentMDK:21703208 pagePK:64168445 pi PK:64168309 theSitePK:4738057,00.html 


\section{APPENDIX A}

NEWSPAPER CODE SHEET

Date coding:

Coder initials:

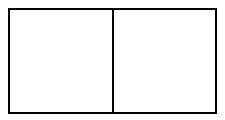

Newspaper: Sai Gon Tiep Thi

Month-Date-Year: (mm/dd/yy):

\begin{tabular}{|l|l|l|l|l|l|}
\hline & & & & & \\
\hline
\end{tabular}

Title of story:

Subject's name:

Subject gender:

Subject age:

Place to live:

Social status:

Marriage status:

Amount of photographs:

Demographics of people:

Who:

Where:

Appeal:
Who:

Where:

Appeal: 
Total of number of emotional phrase in the article

Total number of words in the article

Ratio of emotional phrase/total words

Donations after one month: \$

Donor:

Amount of donor:

Themes in the article: Cross $\mathrm{X}$ :

(1) Health problem:

(2) Too young to work:

(3) Uncertain life:

(4) Heavy burden:

(5) Others: 


\section{APPENDIX B \\ CODE BOOK}

\section{Date coding:}

Enter the information in two digit number as follow: $\mathrm{mm} / \mathrm{dd} / \mathrm{yy}$.

Newspaper name: Sai Gon Tiep Thi newspaper

\section{Article name:}

\section{Main character name:}

\section{Month - Date - Year the article came out.}

Enter the information in two digit number as follow: $\mathrm{mm} / \mathrm{dd} / \mathrm{yy}$. If the story is run on

January the 23,2009 , enter: 01/23/09

\section{Coder:}

Initials of coder

Emotional language is defined by phrases that arouse feelings of pity, sorrow, sadness or anger. Phrases emphasize the adversity, distress, deadlocked circumstances with the implied meaning that there is little or no hope in both near and far future for the featured subject (if there is no support). Phrases describe the featured subject as a victim of domestic violence or an irresponsible one. Phrases imply that the featured subject scarified his or her chance or opportunity for the betterment of others (can be a mother who ignored her health problems and used all the money she has to pay her children's tuition) or carried overload job or work that is not his/her expected responsibility to reduce the burden of his/her significant other.

The emotional phrases will be counted. 
Total of number of emotional phrase in the article: write down the number Total number of words in the article: write down the number

Ratio of emotional phrases to total article words:

Social status:

Enter 0: Kinh - the majority

Enter 1: Other minority group

Subject gender:

Enter 1: Female

Enter 0: Male

If the featured subjects are a poor couple, and if the writer mainly focuses on the husband, choose male. If the writer mainly portrays the wife, choose female. If there is an unbalance between male and female characters (for example one boy and two girls) choose the dominant gender.

\section{Subject age:}

Enter 0: Children or adolescent: under 22

Enter 1: Adults and middle age: from 22 - 60

Enter 2: Elderly: above 60

If the featured subject is an orphan child who depend on his or her relatives, use his/her age (not his relative's age). If there is a name in the title of the story, the person whose name is quoted or implied in the title is the main featured subject.

\section{Geographic location:}

Enter 1: Rural area

Enter 2: Big city 


\section{Marriage status: This is marriage status of the featured subject.}

Enter 1: Still has spouse

Enter 2: Widowed, divorced or single parent

Enter 3: Not applicable (e.g., child)

Donors: is identified as companies and individuals who donated money to specific featured subjects of Vuot Len So Phan campaign. Do not count donors who donated money not for specific featured subjects. The list of donor is provided and updated by Sai Gon Tiep Thi newspaper until February 2010.

Enter 1: Individual

Number of individual donors: Count and write down the number of individual donors in total

Enter 2: Company

Number of company donors: Count and write down the number of company donors in total

Number of donors: Count or sum up the number of all donors including companies and individuals.

\section{Photographs:}

Number of photographs: Write down the amount of photographs used in each story.

\section{Subjects of the photograph:}

Enter 1: If the featured subjects were portrayed.

Enter 2: If the featured subjects were portrayed together with their dependents or significant others. 
Enter 3: If children, grandchildren, dependents or significant others of the featured subjects were portrayed.

\section{Location of the photographs:}

Enter 1: At home: identified "at home" based on the caption below the photographs or indicated in the story or there were things such as (pan, bowl, hang on wall certificate, etc) from the background that indicated that the pictures were taken at home of the featured subjects.

Enter 2: At work: identified "at work" based on the caption below the photographs or the context of the photograph (what the featured subjects were doing at the time they were photographed) and from indication from the story.

Enter 3: cannot tell: if not "at home" or "at work" and

\section{Tone of the photographs:}

Enter 1: Positive: choose this category if the context of the photographs most closely describes happiness, pleasure, joy, hope, confident, protection and love.

Enter 2: Neutral: choose this category if the context of the photographs in the between positive and negative or cannot tell (for example: the featured subjects concentrated to work and/or their faces could not be seen.

Enter 3: Negative: choose this category if the context of the photographs most closely describes sorrow, pain, fear, disappointment, hopelessness, weakness, powerlessness, remorse, resignation and sadness.

\section{Severity themes:}

Will be looking for the presence of the following themes: 
(1) Health problems: The subject has severe health problems and cannot afford health care service and therefore cannot handle heavy work load.

Choose this category only if there is direct statement in the story about the featured subject or his/ her guardian's health problem (can be disability).

(2) Too young to work: The subject is too young to work as an adult (subject is under 22 by the time he or she take over the responsibility).

Choose this category if the featured subjects, who fall into the children and adolescent category, carry at least one regular job or work that can earn money for the family. Do not choose this category if he/ she only helps with housework.

(3) Uncertain life: The future of the subject is uncertain, such as dropping out of school due to the risk of losing his or her resources (e.g. parents, guardian or main income).

Choose this category if the featured subject is at risk of losing his/her income, dropping out of school, being orphaned, being affected by sickness or illness and cannot afford to carry hard work as usual. Choose this category if there are one or more difficulties for the featured subject that did or will happen in the near future.

(4) Heavy burden: The subject has to take care of at least two school age children or dependants not including self. The subject is the only one who can make a living for the whole family.

(5) Other severity themes that might arise: 


\section{APPENDIX C}

Photograph of the featured subjects in the story "Lấy học vấn của con làm gia sản," ran in 12/26/2009

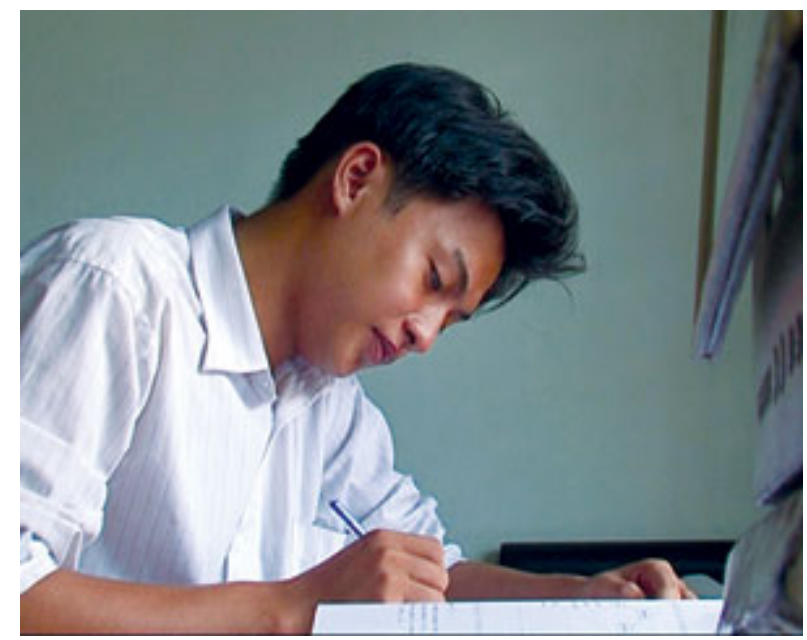

